\title{
PRESENT STATUS OF PLANT DERIVED INDIGO DYE - A REVIEW
}

\author{
Sanchita Sharma ${ }^{1}$, Chandraprabha M.N \\ ${ }^{I}$ Department of Biotechnology, M.S. Ramaiah Institute of Technology, Bangalore - 560054, Karnataka, India \\ ${ }^{2}$ Department of Biotechnology, M.S. Ramaiah Institute of Technology, Bangalore - 560054, Karnataka, India
}

\begin{abstract}
Indigo is the world's most produced synthetic dye because of its use in the denim industry. The wastewaters from the dyeing industry are loaded with pollutant which is the reason there has been an interest in the revival of the indigenous system of dyeing through plant derived indigo. India was the major producer of Indigo in the middle ages with producing $80 \%$ of the world's indigo. It is crucial to understand biosynthetic pathway of indigo production so that the quality and purity of the dye can be enhanced and be at par with the synthetic indigo. In this article we review the present status of the major indigo producing plants with respect to dye yield and purity.
\end{abstract}

Keywords: Indigo, Yield, Indigofera spp., Polygonum tinctorium, Isatis spp., Natural Dye

\section{INTRODUCTION}

India has been considered as pioneer in the art of natural dyeing. It is one the world's twelve mega diversity countries and harbors more than 450 dye yielding plants (Siva 2007). Indigo is one of the most important dye compounds that has been known for dyeing clothes from past 2000 years. It was therefore also referred to as the King of dyes (Xia 1992, Teanglum 2012). India was one of the major producers of plant derived indigo in the middle ages but later during 18th century after the synthesis of synthetic indigo, the market for plant derived indigo started declining and was eventually lost into oblivion (Gulrajani 2001, Kumar 2004). It was due the competition from synthetic indigo which was over $90 \%$ pure and much cheaper than the indigo produced in India mainly from Indigofera tinctoria which had poor yield $(0.2 \%-0.5 \%)$ and purity (20\% to $90 \%)$ (Bechtold 2009). The global market for dyestuffs is about $800 \mathrm{kt}$ (Stoker 1998) of which indigo is the majorly produced dyestuff with approx $200,000 \mathrm{t}$ due to its use in the denim industry for imparting the distinctive blue color (Buscio 2014). Herbal dyes constitute a market of about 1 billion US\$, growing at the rate of $12 \%$ per anum due to the harmful effects of synthetic dyes (Gokhale et al. 2004).

Indigo is not present in the plants as a native compound but its precursors are present as secondary metabolite (Stoker 1998a).The indigo precursor indican (indoxyl $\beta$-Dglucoside) may provide a defence mechanism against several pathogens as secondary metabolites have protective actions (Daykin 2011). Indican is found in higher quantity in the green leaves of the plant and is absent in other tissues. It is localized in the vacuoles of the leaf cells and increases with the growth of the leaves and development of chloroplasts (Minami 2000). The indigenous knowledge of indigo dyeing is still being practiced in some small communities but due to its disappearance from the global market, there is a lack of knowledge regarding the understanding of the biosynthetic pathway of this secondary metabolite (Xia 1992).
However, now there are several growing environmental concerns over the use of synthetic dye because the reducing agent used in the dyeing industry, sodium dithionite is harmful to the environment (Padden 1999). Germany, the biggest supplier and discoverer of synthetic dyes was the first counrty to ban the use of certain azo dyes in 1996 given their allergic and carcinogenic effects of human health (Kar and Borthakur 2008). Therefore several efforts are being made to revive and regenerate the indigo producing plants across the globe in order to improve the dye yield and purity and reintroduce it as an alternative to the synthetic indigo. In this article we review the present status of the major indigo producing plants with respect to dye yield and purity.

Indigo Synthesis in major plant sources: The blue indigo dye has been obtained from various plants originating from different parts of the world mainly Indigofera spp. (Asia, Africa, America), Periscaria (Polygonum) tinctorium (Japan, Europe, China, Korea) and Isatis tinctoria of Europe (Maier 1990, Maugard et al. 2001).

1.Indigofera tinctoria: There are about 250-300 species of Indigofera across the world but not all species yield dye. Indigofera tinctoria produces the superior quality dye than any other plant and is therefore also referred to as true indigo (Teanglum 2012). The British established trade with india due to I. tinctoria. The indigo precursor in I.tinctoria is indican which is found mainly in the leaves with content ranging from $0.2 \%$ to $0.76 \%$ (Feeser 2012). When the plant leaves are damaged, an enzyme $\beta$-glucosidase hydrolyses indican to form indoxyl which dimerises to form insoluble indigo. In the presence of oxygen, indoxyl forms isatin as a side product. The condensation of indoxyl with isatin produces indirubin, a red pigment which is similar to indigo blue in structure (Laitonjam 2011). The indigo formed is insoluble in water so it has to be base-oxidized in order to make it soluble. This soluble form of indigo is called leuco indigo which is a colorless substance and can again be turned into indigo blue after oxidation by air (Chanayath et al. 2002) 
Indigofera $\mathrm{sp}$. is a leguminous plant therefore its roots can deposit nitrogen in the soil. After the dye was extracted from Indigofera, the remaining plant material was used as manure in the paddy fields. Indigofera was a rotational crop which enriched and prepares the soil for the paddy crop. So if indigo is cultivated then after extracting the dye even the plant residue could be used as a fertilizer that can fulfill $50 \%$ requirement of nitrogen leaving no wastage and saving land and money by reducing the use of fertilizers (Balaram 2011).

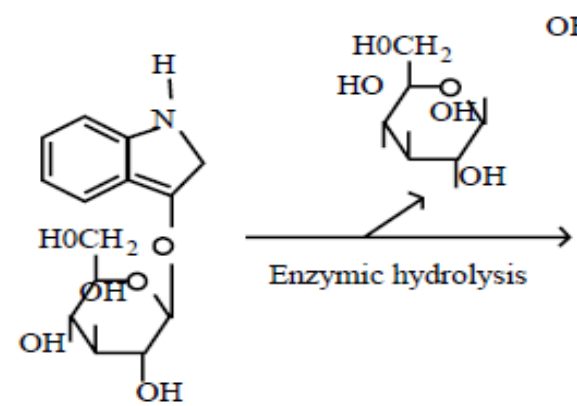

$\mathrm{OH}$

Glucoside indican<smiles></smiles>

Leuco indigo

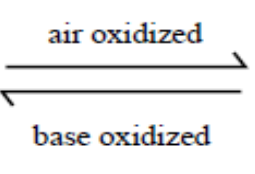

base oxidized<smiles></smiles>

Indoxyl<smiles>CCOCCOCCOCCO</smiles>

Indigo blue

Fig 1: Indigo production pathway in Indigofera tinctoria (Chanayath et. al. 2002)

2. Periscaria (Polygonum) tinctorium: It is also known as dyer's knotweed or Japanese indigo (Koch 2013). It is has more indigo content (3-5 times) than Isatis tinctoria (Bechtold 2009). It contains only one indigo precursor
Indican (Gilbert 2004). When the plant cells of $P$. tinctorium are broken, $\beta$-glucosidase degrades indican into indoxyl and glucose and indoxyl molecule dimerizes by air oxidation to form indigo (biindoline-3,3'-dione) (Minami 2000). (Fig. 2).

Indican

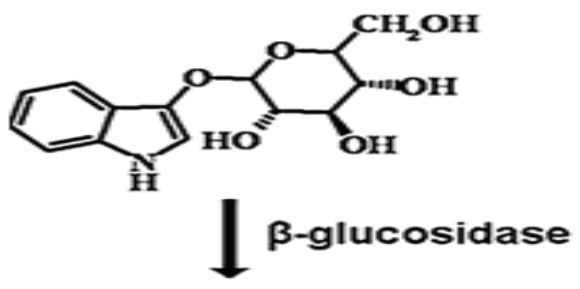

\section{Indoxyl}
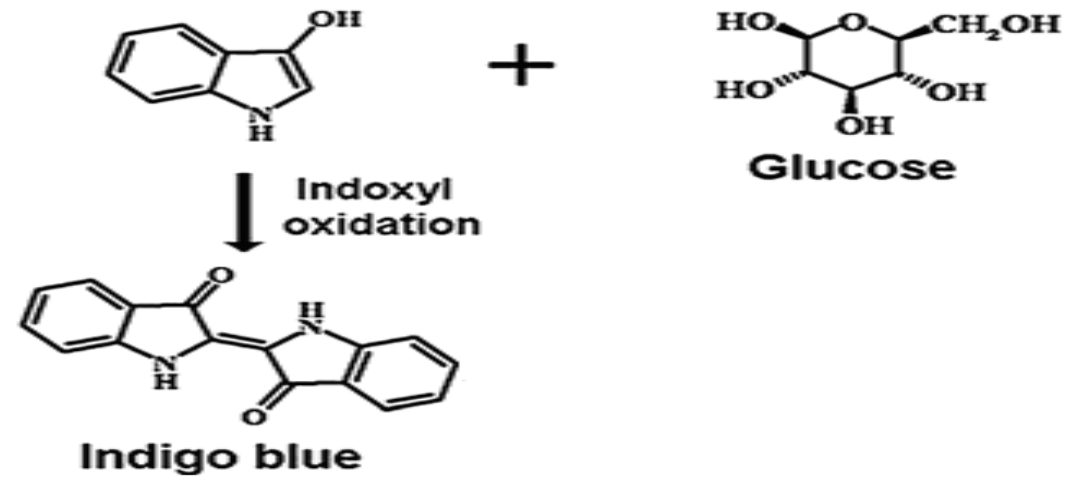

Giucose

Fig. 2: Indigo formation pathway in Periscaria tinctorium. (Daykin 2011) 
3. Isatis spp.: Isatis tinctoria is commonly known as woad and consists of about 30 species most of which can produce indigo (Bechtold 2009). It is the earliest and commonest sources of indigo in Europe. There are two indoxyl derivatives present in the woad leaves, a major precursor isatan B (indoxyl 3-(5-keto-gluconate) and a minor precursor indican (indoxyl 3-O- $\beta$-D-glucoside). Hydrolysis of indican and isatin B forms free indoxyl which dimerises to form indigo. (Kokubun et al. 1998). Indigo is derived from these derivatives and indirubin is formed as a byproduct. (Maugard et al. 2001)

Another species Isatis indigotica Fort. or Chinese woad, is also a popular indigo producing plant On comparison of Isatis tinctoria with Isatis indigotica, the latter showed higher amount of Isatan B (up to $+55 \%$ ) but Isatis indigotica has less suitability and adaptation towards climatic conditions so Isatis tinctoria is a preferred source (Angelini 2007).<smiles>O=C1C(=C2Nc3ccccc3C2=O)Nc2ccccc21</smiles><smiles>CC1CC1COc1c[nH]c2ccccc12</smiles>

Isatin B<smiles>OCC(O)C(O)C(O)C(Oc1c[nH]c2ccccc12)C(O)CO</smiles>

Indican

Fig 3: Indigo formation Pathway in Isatis tinctoria (Daykin 2011)

Yield and Purity of Indigo and its Precursors: Several attempts were made during colonial India to revive the dying Indigo industry in an attempt to meet the competition of synthetic dye. In the late nineteenth century, John Augustus Voelcker suggested the use of high quantity of manure to increase the indigo yield. J. Bridges Lee had registered three specific patents for improving indigo yield. His patents include: applying calibrated pressure on indigo leaves in the steeping vat, slow bath method of oxidation and turning out indigo slabs. Eugene Schrottky registered in Bengal seven patents on various chemical and mechanical processes and sold them to the Bengal Indigo Manufacturing Company, one of the largest indigo companies in Bihar and reportedly his methods helped in increasing the dye yield to 50 pounds per vat as compared to earlier 25.5 pounds per vat (Kumar 2012).

Christopher Rawson proposed an ammonia gas process but his new methods and processes did not pass beyond the experimental stage. Key advance was made at Dalsingserai in terms of success with a new, higher-yielding, foreign variety of indigo procured from abroad - Java indigo. It was capable of consistently giving a 50\% higher yield than the native variety (Ingidofera tinctoria). Java indigo in Bihar suffered from a major incidence of wilt in 1909 leading to a large-scale crop failure (Kumar 2012). Synthetic blue dye has now acquired a major portion of the world market due to the denim industry as about $10^{9}$ blue jeans are produced annually which makes indigo the largest producing synthetic dye (Buscio 2014) therefore a lot of research is going on across the globe for the revival of natural indigo. Several factors that can possibly affect the dye yield such as climatic and environmental factors, different subspecies, modified extraction processes etc. are being studied. Dye yield and purity is variable among different species but has been improved than before.

Modified extraction process: In the earlier attempts made to improve the indigo yield the values ranged from near 0.05 $\mathrm{mg} / \mathrm{g}$ (Kokubun et. al. 1998) but in 1901 Plowright reported dye yield of 3-4.8 $\mathrm{mg} / \mathrm{g}$, based on the method, an extraction method was reported by Stoker et. al. 1998a, that yielded $0.38+-0.12 \mathrm{mg} / \mathrm{g}$ dye from woad. Several modified extraction processes have also been experimented with to improve the recovery of indigo. Hartl and vogl in 2003 reported 0.22 and $0.64 \%$ yield of indigo from leaf dry matter of $P$. tinctorium. Qian et. al. in 2005 recovered more than 95\% indigotin and indirubin from indigo naturalis using high performance liquid chromatographic (HPLC) separation but in 2006, Hou et. al. reported $96.9 \%$ recovery of indigo and indirubin from Baphicacanthus cusia, by a slightly different method involving HPLC. According to a 
study by Laitonjam 2011, maceration of small cut pieces of fresh indigo leaves with water increases the dye yield. It was also suggested that the activity of the enzyme $\beta$-glucosidase was highest in fresh plant leaves and decreases when exposed to heat and dryness (Chayanath 2002, Laitonjam 2011). Kukula-Koch et. al. 2015 observed that a shorter extraction duration increases the indigo content. Comlekcioglu et. al. in 2015 extracted indigo dye from four
Isatis species namely, Isatis tinctoria $\mathrm{L}$ and wild forms of Isatis buschiana Schischkin, Isatis candolleana and Isatis tinctoria L. subsp. corymbosa. Among all the species, the highest ammount of dye was reported in Isatis tinctoria and Isatis candolleana $(4.19 \mathrm{mg} / \mathrm{g}$ and $2.53 \mathrm{mg} / \mathrm{g})$ respectively. They also proposed that yield also depends on the harvesting season of the crop. A list of different extraction procedures for indigo is presented in table 1 .

Table 1: Indigo yield from various extraction methods

\begin{tabular}{|c|c|c|c|}
\hline Plant source & Extraction Condition & $\begin{array}{l}\text { Indigo dye } \\
\text { yield }\end{array}$ & Reference \\
\hline \multirow{3}{*}{ Indigofera tinctoria } & $72 \mathrm{~h}$ maceration of $100 \mathrm{~g}$ leaves $\mathrm{pH} 4.8$ & $4.001 \mathrm{mg} / \mathrm{g}$ & Laitonjam et. al. 2011 \\
\hline & $\begin{array}{l}\text { Chemical extraction via permealization with } \\
\text { methanol }\end{array}$ & $8+/-2 \mu \mathrm{g} / \mathrm{g}$ & Wu et. al. 1999 \\
\hline & $24 \mathrm{~h}$ maceration of $100 \mathrm{~g}$ leaves at $\mathrm{pH} 4.8$ & $12.2 \mathrm{mg} / \mathrm{g}$ & Chayanath et. al. 2002 \\
\hline Polygonum tinctorium & Traditional 'Niram method' of Korea & $\begin{array}{l}21.7 \% \text { (from } \\
1.25 \mathrm{~g} \text { crude } \\
\text { dye at } \mathrm{pH} 3.5 \text { ) } \\
\text { and } 17.8 \% \text { from } \\
1 \mathrm{~g} \text { crude dye at } \\
\mathrm{pH} 6 \text { and } \\
0.810 \% \text { yield } \\
\text { from scale up } \\
\text { production }\end{array}$ & Shin et. al. 2012 \\
\hline \multirow{2}{*}{ Isatis tinctoria } & Hot water application at $\mathrm{pH} 11$ & $4.19 \mathrm{mg} / \mathrm{g}$ & $\begin{array}{l}\text { Comlekcioglu et.al. } \\
2015\end{array}$ \\
\hline & $\begin{array}{l}\text { Hydrolysed in alkaline condition at } \mathrm{pH} 9 \text { and } \\
\text { extracted at } \mathrm{pH} 3\end{array}$ & $554.6875 \mathrm{mg} / \mathrm{g}$ & John et. al. 2015 \\
\hline $\begin{array}{l}\text { Baphicacanthus cusia } \\
\text { Brem. }\end{array}$ & $24 \mathrm{~h}$ maceration of $100 \mathrm{~g}$ leaves at $\mathrm{pH} 4.8$ & $30.1 \mathrm{mg} / \mathrm{g}$ & Chayanath et. al. 2002 \\
\hline Strobilanthus flaccidifolius & $72 \mathrm{~h}$ maceration of $100 \mathrm{~g}$ leaves $\mathrm{pH} 4.8$ & $4.748 \mathrm{mg} / \mathrm{g}$ & Laitonjam et. al. 2011 \\
\hline Lonchocarpus cyanescens & cold maceration in alkaline solution & $20.5 \% \mathrm{wt} / \mathrm{wt}$ & Oduro et.al. 2013 \\
\hline Isatis candolleana & Hot water application at pH 11 & $2.53 \mathrm{mg} / \mathrm{g}$ & $\begin{array}{l}\text { Comlekcioglu et.al. } \\
2015\end{array}$ \\
\hline
\end{tabular}

Role of environmental factors: The role of environmental factors may also affect the dye yield. Some field studies have shown the importance of such environmental factors. Stoker et. al. 1998b reported that indigo yield increases from Isatis tinctoria increases in the presence of sufficient light may be because of an increase in the production of indigo precursors in sunlight. Sales et al. in 2006 studied the difference between species and sowing date on the yield of Isatis Spp. which ranged between $0.4-0.8 \mathrm{~g} / \mathrm{kg}$. Dhanasekaran et al. in 2008 screened 20 germplasms of Indigofera tinctoria for biomass and dye yield and concluded that among all the accessions, IT-5, IT-11, IT-13 showed higher dye yield than the rest and further, IT-5 reported the highest dye yield and biomass. Sandoval-Salas in 2006 studied the effect of harvest time on the dye yield of Indigofera suffruticosa Mill, and found that the accumulated indigo in the leaves was about $0.01 \mathrm{~g}^{-1}$. Islam et al. in 2007 reported an average yield of 0.00485 per g plant material. They also reported that when the water temperature is increased during soaking, the dye yield also increases. In 2012, Orsini et al. evaluated the effect of mineral and nitrogen fertilization on indigo dye yield and biomass production of Isatis tinctoria. They reported that nitrogen fertilization has no effect on the dye concentration but it does increases the biomass production.

Other Factors: It was seen that addition of other enzymes have no significant role in the hydrolysis of indican. In 2003, Angelini et al. evaluated the activity of enzyme $\beta$ Glucosidase in Polygonum tinctorium for indigo production where the original enzyme was compared with two other enzymes, sweet almond $\beta$-glucosidase and Novarom G. The results showed that Novogram $G$ was capable of hydrolyzing indican more efficiently than almond $\beta$ glucosidase. In another study Angelini et al. in 2004, observed the effect of climatic factors on the indican content and indigo yield of Polygonum tinctorium. The outcome showed that among the three lines of species being tested, there was a significant difference in the indican content that ranged from $12-25 \mathrm{~g}$ per $\mathrm{kg}$, highest during rainy season. In 2007 Angelini et. al. performed a comparative study between Isatis tinctoria and Isatis indigotica and observed a significant difference between the major indigo precursors isatan B. For Isatis tinctoria isatan B ranged between 1-2 
$\mathrm{g} / \mathrm{kg}$ where as for I. indigotica it was between $4.9-1.5 \mathrm{~g} / \mathrm{kg}$. There was no significant difference between minor indigo precursor indican $(0.3-0.7 \mathrm{~g} / \mathrm{kg})$. But Indigofera tinctoria is a preferred crop due to its higher re growth capacity and biomass production.

Apart from the climatic conditions, certain impurities also tend to reduce the indigo yield and purity. Garcia-Macias and John in 2004 proposed that highly pure natural indigo can be produced from Isatis tinctoria that can meet the standards of synthetic dye, by eliminating the impurities. The study focused on reducing the impurities and recovering maximum pure indigo. According to John et al. 2015, in $P$. tinctorium the purity of the indigo varies from $5 \%$ to $60 \%$ when produced by the traditional method. He observed that washed leaves gave more pure indigo dye $18-24 \%$ with an average yield of $0.5 \mathrm{~g} / \mathrm{kg}$. Sedimentation of indigo in acid medium and washing raw indigo in dilute $\mathrm{HCl}$ after grinding the dried product also improved its purity up to $68 \%$.

Discussion: The use of indigo blue dye goes back as long as the invention of textile itself. It has been used as a dye since the neolithic period. The remains of indigo blue have been found in all great civilizations, Egyptians, Romans. During colonial era the British established trade with India due to its most superior quality dye obtained from Indigofera tinctoria which once occupied world's $80 \%$ market. Being a vat dye indigo requires no mordant before dyeing has a good color fastness. It can become an important source of livelihood for the local artisans and farmers. Synthetic dyes are a much cheaper and pure comparatively but due to its carcinogenic and pollution related affects its usage is now being questioned. Some countries have even imposed a ban on some dyes because of their hazardous and non biodegradable effects on the other hand these plant derived dyes contain antimicrobial and antifungal properties. Moreover the remains obtained after extraction can be used as a fertilizer. Therefore there has been a growing demand for naturally derived indigo dye and the results from the research shows that a significant progress has been made for some European plant species extracted with $68 \%$ purity. However there is limited information available on the Indian species Indigofera therefore a fundamental research on this species is desirable. The major barrier in the commercialization of natural dyes is its high cost and low reproducibility therefore targeted efforts are required in this direction which can make the natural dye extraction more economical.

\section{ACKNOWDGEMENT}

The authors are thankful to the Women Scientists Fellowship Scheme - WOS-B, Department of Science and Technology, Government of India for financial support (Grant No. NASI/SoRF-I/2014-15/53).

\section{REFERENCES}

[1] Angelini LG, Campeol E, Tozzi S, Gilbert KG, Cooke DT, \& John P (2003) A new HPLC-ELSD method to quantify indican in polygonum tinctorium
L. and to evaluate $\beta$-glucosidase hydrolysis of indican for indigo production. Biotechnology Progress 19 (6): 1792-1797

[2] Angelini LG, Tozzi S, Nassi O Di Nasso N (2004) Environmental factors affecting productivity, indican content, and indigo yield in polygonum tinctorium ait., a subtropical crop grown under temperate conditions. J Agri and Food Chem 52 (25): 75417547

[3] Angelini LG, Tozzi S, Nassi o Di Nasso N (2007) Differences in leaf yield and indigo precursors production in woad (isatis tinctoria L.) and chinese woad (isatis indigotica fort.) genotypes. Field Crops Research 101 (3): 285-295

[4] (Balaram 2011) Eco-friendly dyes of India IN: National Workshop and Seminar on "Vegetable dye and its application on textiles". Available via http://www.ulm.edu/ joydeep/Files/Vegetable\%20dy es_pg-118.pdf

[5] Bechtold T, Mussak R (2009) Handbook of natural colorants. John Wiley \& Sons, Ltd, Chichester, UK. doi: 10.1002/9780470744970.ch18

[6] Buscio V, Crespi M, Gutiérrez-Bouzán C (2014) A critical comparison of methods for the analysis of indigo in dyeing liquors and effluents. Materials 7 (9): 6184-6193

[7] Chanayath N, Lhieochaiphant S, Phutrakul S (2002) Pigment Extraction Techniques from the Leaves of Indigofera tinctoria Linn. and Baphicacanthus cusia Brem. and Chemical Structure Analysis of Their Major Components. CMU Journal 1 (2): 149-160

[8] Comlekcioglu, N, Efe L, Karaman S (2015) Extraction of indigo from some isatis species and dyeing standardization using low-technology methods. Brazilian Archives of Biol and Tech 58 (1):96-102

[9] Dhanasekaran D, Sekar K (2008) Screening of Indian Indigo (Indigofera tinctoria L.) germplasm for biomass and dye yield. Plant Archives 8 (2):829-832

[10] Feeser A, Goggin MD, Tobin BF (2012) The Materiality of Color- The production, circulation and application of dyes and pigments. MPG Books Group, UK

[11] Garcia-Macias P, John P (2004) Formation of natural indigo derived from woad (isatis tinctoria L.) in relation to product purity. J Agri and Food Chem 52 (26): 7891-7896

[12] Gokhale SB, Tatiya AU, Balkiwal SR, Fursule RA (2004) Natural dye yielding plants in 9India. Natural Product Radiance 3 (4): 228-234

[13] Gulrajani ML (2001) Present status of natural dyes. Indian J Fibre and Textile Research 26 (1-2):191-201

[14] Hartl A, Vogl CR (2003) The Potential Use of Organically Grown Dye Plants in the Organic Textile Industry: Experiences and Results on cultivation and Yields of Dyer's Chamomile (Anthemis tinctoria L.), Dyer's Knotweed (Polygonum tinctorium Ait.), and Weld (Reseda luteola L.). J Sustainable Agri 23 (2): $17-40$ 
[15] Hou HC, Liang SZ (2006) Determination of indirubin and indigo in baphicacanthus cusia (nees) bremek by HPLC. Zhong Yao Cai $=$ Zhongyaocai $=$ Journal of Chinese Medicinal Materials 29 (7): 681-682

[16] John P, Seymour K, Macias PG (2015) The Production of Natural Indigo with a High Purity. AvailableviaResearchgate.

https://www.researchgate.net/publication/268362162 _The_Production_of_Natural_Indigo_with_a_High_P urity. Cited 26 Nov 2015

[17] John P, Angelini LG (2009) Indigo - agricultural aspects. In: Bechtold, T. and Mussak, R. (eds.) Handbook of Natural Colorants, John Wiley and Sons Ltd, Chichester, 75-104 doi: 10.1002/9780470744970

[18] Kar A, Borthakur SK (2008) Dye yielding plants of Assam for dyeing handloom textile products. Indian J Traditional Knowledge 7 (1):166-171

[19] Kokubun T, Edmonds J, John P (1998) Indoxyl derivatives in woad in relation to medieval indigo production. Phytochemistry 49 (1):79-87

[20] Kukuła-Koch W, Głowniak K, Koch W, Kwiatkowski S (2013) Optimization of temperature affected extraction of indigo dye in the leaf extracts of polygonum tinctorium ait. cultivated in poland preliminary studies. Acta Poloniae Pharmaceutica Drug Research 70 (3):579-583

[21] Kukula-Koch W, Koch W, Stasiak N, Głowniak K, Asakawa Y (2015) Quantitative standarization and CPC-based recovery of pharmacologically active components from polygonum tinctorium ait. leaf extracts. Industrial Crops and Products 69: 324-328

[22] Kumar P (2007) Plantation science: Improving natural indigo in colonial india, 1860-1913. British Journal for the History of Science 40 (4):537-565

[23] Kumar P (2012) Indigo Plantations and Science in Colonial India. Cambridge University Press, New York

[24] Laitonjam WS, Wangkheirakpam SD (2011) Comparative study of the major components of the indigo dye obtained from Strobilanthes flaccidifolius Nees. and Indigofera tinctoria Linn. International Journal of Plant Physiology and Biochemistry 3 (7):108-116

[25] Maier W, Schumann B, Groger D (1990) Biosynthesis of indoxyl derivates in Isatis tinctoria and Polygonum tinctorium. Phytochemistry 29: 817819

[26] Maugard T, Enaud E, Choisy P, Legoy MD (2001) Identification of an indigo precursor from leaves of Isatis tinctoria (woad). Phytochemistry 58: 897-904

[27] Minami Y, Nishimura O, Hara-Nishimura I, Nishimura M, Matsubara H (2000) Tissue and intracellular localization of indican and the purification and characterization of indican synthase from indigo plants. Plant and Cell Physiol 41 (2):218-225

[28] Orsini R, Aquilanti L, Osimani, Serrani L, Baldini G, Seddaiu G, Santilocchi R (2012) Isatis tinctoria L.: Biomass production and indigo dye yield as influenced by mineral or organic nitrogen fertilization. Agrochimica 56 (6):292-308

[29] Oduro WO, Addo-Yobo F (2013) Enhancing the Value of Indigo-Blue Dyes from Lonchocarpus Cyanescens Leaves. International J Applied Science and Technology 3 (5):78-86

[30] Padden AN, Dillon VM, Edmonds J, Collins MD, Alvarez N, John P (1999) An indigo-reducing moderate thermophile from a woad vat, clostridium isatidis sp. nov. International $\mathrm{J}$ Systematic Bacteriology 49 (3):1025-1031

[31] Plowright CB (1901) On woad as a prehistoric pigment. Journal of the Royal Horticultural Society 26:33-40

[32] Qian B, Panichayupakaranant P, Sirikatitham A, Zhang RP, Guo YD, Wu YQ (2005) Quantitative HPLC determination of indigotin and indirubin in indigo naturalis. [Determinación cuantitativa de indigotina e indirubina en el índigo natural mediante cromatografía líquida de alto rendimiento (HPLC)]. Ars Pharmaceutica 46 (4):429-438

[33] Sales E, Kanhonou R, Baixauli C, Giner A, Cooke D, Gilbert K, Ros R (2006) Sowing date, transplanting, plant density and nitrogen fertilization affect indigo production from isatis species in a mediterranean region of spain. Industrial Crops and Products 23 (1): 29-39

[34] Sandoval-Salas F, Gschaedler-Mathis A, Vilarem G, Méndez-Carreto C (2006) Effect of harvest time on dye production in indigofera suffruticosa mill [Efecto del tiempo de cosecha sobre la producción de colorantes en Indigofera suffruticosa Mill]. Agrociencia 40 (5):585-591

[35] Shin Y, Yoo D, Kim K (2012) Process Balance of Natural Indigo Production based on Traditional Niram Method. Textile Coloration and Finishing 24 (4):253-259

[36] Siva R (2007) Status of natural dyes and dye-yielding plants in India. Current Science 92 (7): 916-925

[37] Stoker KG, Cooke DT, Hill DJ (1998a) An improved method for the large-scale processing of woad (isatis tinctoria) for possible commercial production of woad indigo. Journal of Agricultural Engineering Research 71 (4):315-320

[38] Stoker KG, Cooke DT, Hill DJ, (1998b) Influence of light on natural indigo production from woad (Isatis tinctoria). Plant Growth Regul 25:181-185

[39] Teanglum A, Teanglum S, Saithong A (2012) Selection of Indigo Plant Varieties and Other Plants that Yield Indigo Dye. Procedia Engineering 32:184 190

[40] Xia Z, Zenk MH (1992) Biosynthesis of indigo precursors in higher plants. Phytochemistry 31: 2695-2697 